\title{
Effect of Processing Method on Composition and Consumer Acceptability of Camel (Camelus dromedarious) Meat and Beef. ${ }^{1}$ Muhammad, B.F., ${ }^{1}$ Mahmud, A.B. AND ${ }^{2}$ Mustapha, A. \\ ${ }^{1}$ Department of Animal Science, \\ ${ }^{2}$ Department of Agricultural Economics and Extension, Bayero University, PMB 3011, Kano, Nigeria.
} Abstract

The study was carried out to investigate the chemical composition and sensory characteristic of processed camel meat and beef. Fresh meat from hindlimb Longissimus dorsi of camel and bull were processed into kilishi, balangu, and soye. The unprocessed meat was used as control. The meat and meat products were subjected chemical analysis to determine moisture, protein, fat, and mineral contents ( $\mathrm{Na}, \mathrm{K}, \mathrm{Ca}, \mathrm{Mg}, \mathrm{Cu}, \mathrm{Fe}$ and $\mathrm{Zn}$ ). The results showed that raw camel meat had significantly $(p<0.05)$ higher moisture content $(76.77 \%)$ than beef $(71.29 \%)$. Similarly, camel meat processed into balangu had higher moisture content (73.94\%) than that of beef (62.27\%). The kilishi of beef and camel meat had the lowest moisture of $9.89 \%$ and $10.30 \%$, respectively. Processing method significantly $(p<0.05)$ affected protein contents of raw beeffrom $18.88 \%$ to $20.26 \%$ in balangu, $19.69 \%$ in kilishi and $24.78 \%$ in soye. Protein content of raw camel meat was increased significantly $(p<0.05)$ from $15.16 \%$ to $20.57 \%$ in balangu, $17.56 \%$ in kilishi and $18.10 \%$ in soye. The fat content of camel meat $(19.33 \%)$ differ significantly $(p<0.05)$ from that of beef $(15.37 \%)$; and the processed meat products showed significantly $(p<0.05)$ higher fat contents than raw meat. The ash contents of both beef (4.20\%) and camel meat (4.70\%) kilishi were significantly $(p<0.05)$ higher compared to other products. Camel meat products contain more minerals than beef except for $\mathrm{Cu}(5.15 \mathrm{mg} / \mathrm{g})$ and $\mathrm{Fe}(1.43 \mathrm{mg} / \mathrm{g})$. The colour and flavour of beef and camel meat soye were rated very good significantly $(p<0.05)$ higher than kilishi and balangu rated between good and satisfactory. The overall acceptability ratings of beef kilishi (7.1) and balangu (7.4) were significantly $(p<0.05)$ higher than camel meat kilishi (6.6) and balangu (4.7). However the overall acceptability of soye from both species was rated same and excellent. It could be concluded that beef and camel meat compare favourably in nutrients and consumer acceptability ratings. It was recommended that camel meat be adopted for use in soye, kilishi and balangu making at small scale and commercial production levels.

Keywords: Camel meat and beef, kilishi, balangu, and soye, processing methods.

\section{Introduction}

Meat and meat products are vital sources of essential protein and other nutrients required for healthy growth and development. The amount of meat consumed by an individual varies with income, social status, economic and political influence and religious beliefs (FAO, 1997). Lathan (1997) stated that $\backslash$
The quantity of meat consumed in developing countries largely depends on the price of meat in relation to individual income and meat availability.

A wide range of processing techniques are used for different meat preparations. Several processing methods have been identified for meat and include boiling, 
frying, roasting, smoking and shredding (Okubanjo, 1988). Cooking methods have been known to affect degree of doneness in meat as well as its desirability and consumer acceptability (lkeme, 1990). In northern Nigeria, tsire, balangu, kilishi, dambun-nama and ragadada are the commonest meat products (Bube, 2003). Often, tsire, balangu and kilishi are collectively referred to as Suya (Igene and Abulu, 1984). Earlier study (Alongo and Hiko, 1981) reported detailed description of Suya products consumed in northern Nigeria.

Beef, mutton, chevon and of recent camel meat are being used in the production of Tsire and Balangu that are commonly served or sold along streets, in club houses, at picnics, restaurants and within institutions of learning. These products are now mass-consumed fast foods, whose consumption is invariant with respect to ethnicity, religion, socioeconomic factors and sex (Igene and Mohammed, 1983). The consumer attitude to meat shows preference depending on a criteria considered to be important (Apata et al., 2008), such criteria may include species type, age at slaughter and eating quality of meat (Joseph et al.,1995). Sensory evaluation is an excellent guide to nutrition and in choice of meat processing method (Larson et al., 1992). The method used in meat processing affects its composition and biological value (FAO, 1997).

Camel meat is low in cholesterol and high in quality proteins of high biological value (Anon, 2008). It provides useful amount of riboflavin and niacin, thiamine, iron, zinc and vitamins $\mathrm{A}$ and $\mathrm{C}$ (Lathan,1997). Camel carcass provides a substantial amount of meat. The dromedary carcass weighs $400 \mathrm{~kg}$ or more in males and $300 \mathrm{~kg}$ or less in females which vary from location to location and based on plane of nutrition prior to slaughter (Kurtu, 2004; Anon, 2002; Wilson, 1984). In Nigeria, a mean carcass weight of $195 \mathrm{~kg}$ was reported for camels slaughtered in Kano metropolitan abattoir (Muhammad and Akpan, 2008). The dromedary can survive, reproduce and produce meat in environmental conditions difficult for other domestic livestock (Dawood, 1995). The camel could go up to 7 days with little or no food and water and can lose a quarter of its body weight without impairing on its normal function (Wilson, 1984) making its husbandry relative to cattle in dry areas, easy.

The consumption of camel meat in Nigeria is low compared to other livestock despite camel meat being cheaper (Muhammad, 2008). An identified limitation to camel meat consumption has to do with its acceptability among meat consumers related to method of processing (Maya, 2004). In most developing countries, meat processing techniques are not well developed (Martin, 2001). The methods used are still rural based on past generation ideas (Okubanjo, 1988). The meat of different animal species has different degree of tenderness and composition. Therefore, a suitable method of processing is necessary to enable the release of desirable meat contents (Aduku and Olukosi, 2000). The objective of this study is to evaluate the effect of different processing methods on chemical composition and assess the consumer preference to differently processed camel meat and beef.

\section{Materials and Methods}

Study area

The study was conducted at the Department of Animal Science, Bayero University Kano. Kano State lies between longitude $9^{\circ} 30^{\prime}$ and $12^{\circ} 30^{\prime}$ North and 
latitude $8^{\circ} 42^{\prime}$ and $9^{\circ} 30^{\prime}$ East in the semi arid region of Northern Nigeria The State occupies a land area of $20,400 \mathrm{~km}^{2}$ with a population of over ten million people (Census, 2006). Hausa-Fulani are the major ethnic group in the area and Islam is the dominant religion. The climate of Kano is hot during dry season and cold during harmattan. The ambient temperatue ranges from $16.6^{\circ} \mathrm{C}$ to $42.8^{\circ} \mathrm{C}$ in the months of January to June and $23.9^{\circ} \mathrm{C}$ to $26.7^{\circ} \mathrm{C}$ in July to December (Anon, 2010). An average monthly precipitation of 0 to $30 \mathrm{~mm}$ was recorded in January to June and 780 to $1320 \mathrm{~mm}$ in July to December (KNARDA, 2001). Trading is the main occupation of the people living in the metropolis of Kano while in other areas farming is the main occupation.

\section{Meat Processing Methods}

Fresh meat (15kg each) from Longissimus dorci musle of both adult male camel aged 7 years and a bull aged 6 years (Barnajee, 2005), were obtained from the municipal abattoir and used the study. The ligaments and tendons were carefully removed from selected meat sample and washed twice in clean water and processed into balangu, kilishi and soye as described in the following sub-sections.

\section{Preparation of Balangu}

A total of $2.5 \mathrm{~kg}$ each of fresh camel meat and beef were cut into slices $(1 \mathrm{~cm}$ thick and $20-30 \mathrm{~cm}$ length) using a sharp knife, the sliced meat was placed over a glowing fire on a wire mesh to roast, similar to what was obtained locally in the study area. Groundnut oil, salt $(\mathrm{NaCl})$, masoro, dried ginger, kanunfari and other seasonings (Table 1) were added while the meat was roasted over burning charcoal in line with the reports of Farouk et al., (1992). The meat was turned 3 to 4 times at 7 to 10 minutes interval to ensure adequate roasting of both sides of the meat cuts. The roasting process lasted for about 30 minutes.

Preparation of Kilishi.

Another $5 \mathrm{~kg}$ each of camel meat and beef, was cut and sliced into long pieces of about 0.2 to

Table 1: Proportion of ingredients used in meat preparation.

\begin{tabular}{ll} 
Ingredient (Hausa name) & Proportion in mixture (g/kg) \\
\hline Masoro (Piper guinease ) & 12.0 \\
Kanunfari ( Eugenia caryophyllata & 5.0 \\
Chitta ( Afromomum meleginata $)$ & 5.0 \\
Borkono ( Capsicum frustescens $)$ & 40.0 \\
Tattasai ( Capsicum esculentum ) & 45.0 \\
Albasa ( Allium cepa ) & 120.0 \\
Citta mai yatsu ( Zingiber officinale & 24.0 \\
Maggi seasoning & 20.0 \\
Thyme seasoning & 5.0 \\
Gishiri (NaCl) & 15.0 \\
*Decorticated groundnut seeds & 6.0 \\
* Kuli - kuli (Defatted groundnut cake) & 350.0 \\
*used in kilishi preparation only &
\end{tabular}

*used in kilishi preparation only

Table 2: Chemical composition (\%) of raw and differently processed beef and camel meat

\begin{tabular}{|c|c|c|c|c|c|c|c|c|c|}
\hline & \multicolumn{4}{|l|}{ Beef } & \multicolumn{5}{|c|}{ Camel meat } \\
\hline & raw & balangu & kilishi & soye & raw & balangu & kilishi & soye & $\mathrm{SE} \pm$ \\
\hline Moisture & $71.29^{\mathrm{c}}$ & $62.27^{\mathrm{d}}$ & $9.89^{g}$ & $30.06^{\mathrm{f}}$ & $76.77^{a}$ & $73.94^{b}$ & $10.30^{g}$ & $36.91^{\mathrm{e}}$ & 0.300 \\
\hline Protein & $18.88^{\mathrm{d}}$ & $20.26^{\mathrm{bc}}$ & $19.69^{\mathrm{c}}$ & $24.78^{\mathrm{a}}$ & $15.16^{\mathrm{f}}$ & $20.57^{\mathrm{b}}$ & $17.56^{\mathrm{e}}$ & $18.10^{\mathrm{e}}$ & 0.191 \\
\hline Fat & $15.37^{\mathrm{f}}$ & $32.51^{\mathrm{a}}$ & $29.65^{b}$ & $29.61^{\mathrm{b}}$ & $19.33^{\mathrm{e}}$ & $25.69^{\mathrm{c}}$ & $24.70^{\mathrm{d}}$ & $29.10^{\mathrm{b}}$ & 0.187 \\
\hline Ash & $2.20^{\mathrm{c}}$ & $2.10^{d}$ & $4.20^{\mathrm{ab}}$ & $3.20^{\mathrm{b}}$ & $2.00^{\mathrm{d}}$ & $2.30^{\mathrm{c}}$ & $4.70^{\mathrm{a}}$ & $3.40^{\mathrm{b}}$ & 0.167 \\
\hline
\end{tabular}


$0.4 \mathrm{~cm}$ thick, $5 \mathrm{~cm}$ long and $10 \mathrm{~cm}$ width using sharp knife. The sliced meat was spread out under the sun on a rack (made of sorghum stalks) for 18 hours to dry to less than $40 \%$ moisture level (Muhammad and Muhammad, 2007). The meat was screened from dust and flies using nets. The following day, the dried meat was further prepared by smearing it with a slurry made by forming a paste of groundnut cake (ground), dried ginger, masoro, kanunfari pepper, onions, decorticated groundnut seeds, table salt (Nacl) and water as shown in Table 1. The meat was roasted over a low burning charcoal fire about 15 minutes (Igene, 1983). The kilishi obtained was used for the study.

\section{Preparation of Soye}

Fresh meat of both species ( $2 \mathrm{~kg}$ each) was cut into chunks of $2 \times 1 \times 3 \mathrm{~cm}^{3}$. The chunks of meat of camel meat and beef were placed into separate cooking pots containing 3 liters of water and cooked for 10 minutes at $60-70^{\circ} \mathrm{C}$. A medium sized onion ball, salt $(\mathrm{NaCl})$ and thyme were added into the pot (Table 1). The two meat types were then cooked at $90^{\circ} \mathrm{C}$ for 30 to 45. After cooking the meat chunks were drained for 5 to 10 minutes in a colander and then deep fried in 2.5litres of groundnut oil for 10 minutes to obtain soye used in the study.

Proximate Analyses

Both raw and meat products (balangu, kilishi and soye) from the two species of camel and cattle were subjected to chemical analysis to determine the moisture, total protein, total fat and ash contents according to the methods outlined by AOAC (1990). The major elements, $\mathrm{Na}, \mathrm{K}, \mathrm{Ca}, \mathrm{Mg}$, and trace elements $\mathrm{Cu}, \mathrm{Fe}$ and $\mathrm{Zn}$ contents of the different meat products were determined using atomic absorption spectrophotometer.

\section{Sensory Evaluation}

The meat products (balangu, kilishi and soye) from the two species of camel and cattle were subjected to sensory evaluation. A sensory evaluation ballot based on a 9-point hedonic scale of 1-very bad, 2-bad, 3-imperfect, 4- sufficient, 5mediocre, 6-satisfactory, 7-good, 8-very good and 9-excellent was used for data collection (Williams. 1982). The test panel comprised of staff and students, male and female, aged between 25 and 55 years. The panelists were served the meat products one at a time and water was provided for them to rinse their mouth before the next product was served. The panelist's response in term of acceptability, colour, texture, flavour and tenderness were recorded.

Data collection and analysis

The data collected on chemical composition and sensory evaluations were subjected to analysis of variance in a Completely Randomised Design using General Linear Model of the Minitab. Significantly different means were separated using Duncan Multiple Range Test (Steel and Torrie, 1980).

\section{Results and Discussion}

The chemical composition of differently processed camel meat and beef are shown in Table 2. The results indicated a significant difference in the moisture content due to species and processing methods. The raw camel meat had significantly $(\mathrm{p}<0.01)$ higher moisture content $(76.77 \%)$ than beef $(71.29 \%)$. It is often quoted that adult mammalian muscle is $75 \%$ moisture which varies considerably between species, muscle type and processing method (Casey, 1992). Schontfeld (1989) reported mean moisture content of 63.9 to $65.4 \%$ in cooked muscle of lamb, Angora and Boer goats. 
Table 3: Mineral composition $(\mathrm{mg} / \mathrm{g})$ of differently processed camel meat and beef

\begin{tabular}{|c|c|c|c|c|c|c|c|c|c|}
\hline \multirow[b]{2}{*}{ Minerals } & \multicolumn{4}{|c|}{ Camel meat } & \multicolumn{4}{|c|}{ Beef } & \multirow[b]{2}{*}{$\mathrm{SE} \pm$} \\
\hline & raw & balangu & kilishi & soye & raw & balangu & kilishi & soye & \\
\hline \multicolumn{10}{|l|}{ Major } \\
\hline $\mathrm{Na}$ & $2.02^{\mathrm{g}}$ & $2.23^{f}$ & $4.05^{b}$ & $4.66^{\mathrm{a}}$ & $1.23^{\mathrm{h}}$ & $3.44^{\mathrm{e}}$ & $3.85^{\mathrm{c}}$ & $3.64^{\mathrm{d}}$ & 0.0012 \\
\hline K & $10.01^{\mathrm{b}}$ & $10.59^{\mathrm{a}}$ & $10.13^{\mathrm{b}}$ & $7.45^{\mathrm{e}}$ & $7.22^{f}$ & $8.38^{\mathrm{d}}$ & $9.78^{c}$ & $4.66^{g}$ & 0.0008 \\
\hline $\mathrm{Ca}$ & $1.89^{\mathrm{d}}$ & $2.27^{\mathrm{b}}$ & $2.46^{\mathrm{a}}$ & $2.08^{\mathrm{c}}$ & $1.33^{\mathrm{e}}$ & $2.08^{\mathrm{c}}$ & $2.27^{\mathrm{b}}$ & $1.33^{\mathrm{e}}$ & 0.0302 \\
\hline $\mathrm{Mg}$ & $4.98^{\mathrm{c}}$ & $7.77^{\mathrm{b}}$ & $7.88^{\mathrm{a}}$ & $4.67^{\mathrm{e}}$ & $4.03^{f}$ & $4.82^{\mathrm{d}}$ & $7.88^{\mathrm{a}}$ & $4.66^{\mathrm{e}}$ & 0.0008 \\
\hline \multicolumn{10}{|l|}{ Trace } \\
\hline $\mathrm{Cu}$ & $1.64^{\mathrm{h}}$ & $4.37^{\mathrm{c}}$ & $2.29^{f}$ & $4.64^{\mathrm{b}}$ & $1.91^{\mathrm{g}}$ & $3.22^{\mathrm{d}}$ & $2.40^{\mathrm{e}}$ & $5.15^{\mathrm{a}}$ & 0.0008 \\
\hline $\mathrm{Fe}$ & $1.35^{\mathrm{e}}$ & $2.34^{\mathrm{a}}$ & $1.67^{\mathrm{b}}$ & $1.30^{\mathrm{f}}$ & $0.73^{\mathrm{g}}$ & $1.30^{\mathrm{f}}$ & $1.51^{\mathrm{c}}$ & $1.41^{\mathrm{d}}$ & 0.0007 \\
\hline $\mathrm{Zn}$ & $11.39^{\mathrm{b}}$ & $12.39^{\mathrm{q}}$ & $7.17^{g}$ & $10.86^{\mathrm{c}}$ & $8.76^{\mathrm{f}}$ & $9.29^{\mathrm{e}}$ & $5.31^{\mathrm{h}}$ & $10.40^{\mathrm{d}}$ & 0.0008 \\
\hline
\end{tabular}

However, the moisture contents of both raw camel meat $(76.77 \%)$ and beef $(71.29 \%)$ were significantly $(p<0.01)$ higher than after being processed into balangu (73.94 and 62.27\%), kilishi (9.89 and $10.30 \%$ ) and soye (36.91 and $30.06 \%$ ). The extent and rate at which moisture is lost from products during processing has been shown to depend largely on temperature and time as well as presence of additives such as salt and polyphosphates (Igene and Farouk, 1990). Kilishi is a product of sun-drying and roasting both of which drastically reduce moisture through water loss by convection and conduction. Egbunike and Okubanjo (1999) observed similar drying behaviour in kilishi before and after infusion in both oven dried and sundried regimes. A low moisture content of $9.8 \%$ and $10.30 \%$ were recorded on beef and camel kilishi respectively, which were statistically $(p<0.01)$ lower than soye ( 30.06 and $36.9 \%$ ) which in turn is significantly lower than balangu (62.27 and $73.94 \%$ ) of both camel meat and beef products. Kilishi processing involved loss of volatile substances from raw meat at initial stage of drying which became rapid due to loss of free water and the final product contained less than $40.0 \%$ moisture (Farouk et al., 1992).

The processing methods significantly affected the crude protein content of beef balangu (20.26\%), kilishi (19.69\%) and soye $(74.78 \%)$ and camel meat (balangu $20.57 \%$, kilishi $17.56 \%$ and soye $18.10 \%$ ) products compared to that of raw beef $(18.88 \%)$ and camel meat (15.16\%). This is similar to the report of Omojola (2008) that water loss during cooking depend on time, temperature, method of cooking, size of sample, heat penetration, meat composition and increases concentration of fat and protein. The results obtained indicated that though heat treatment denature protein due to possible over heating during processing, the resulting moisture loss tend to concentrate the nutrients in the final products. Oguntona and Akinyele (1995) reported that beef with moderate fat had $63 \%$ moisture, $18.2 \%$ protien, and $6.0 \%$ fat. A crude protein value of $26.6 \%$ was reported for lamb's longissimus muscle before processing slightly higher than that obtained for raw camel meat (Casey, 1992). DAA (2007) reported an average protein content value of $23.2 \mathrm{~g} / 100 \mathrm{~g}$ in lean component of Australian red meat. Raw red muscle meat contains about 20 to $25 \mathrm{~g} / 100 \mathrm{~g}$ protein and processing changes the concentration to 28 to $36 \mathrm{~g} / 100 \mathrm{~g}$ due to decrease in water content and concentration of other nutrients.

The total protein content of beef soye $(24.78 \%)$ is the highest which could be 
attributed to deep frying in vegetable oil which rapidly affect protein structure and composition compared to the heat treatment involved in balangu and kilishi with protein content values of $20.26 \%$ and $19.69 \%$ respectively. However, camel meat balangu had higher protein content $(20.57 \%)$ compared to kilishi $(17.56 \%)$ and soye (18.10).

The fat content of raw camel meat (19.33\%) was significantly different from that of beef $(15.37 \%)$. Bube (2003) reported similar fat content value of $27.0 \%$ in goat meat Kilishi and attributed it to groundnut oil added during processing. The fat content of the beef balangu $(32.51 \%)$ was significantly $(\mathrm{p}<0.01)$ higher than that of kilishi $(29.65 \%)$ which is statistically at par with that of soye $(29.61 \%)$ product. Weiss (1988) observed that during deep frying meat in groundnut oil it tend to take up the oil which becomes a significant part of the end product. Slightly, lower fat content of $12.1 \%$ and $12.3 \%$ were reported in mutton tsire and balangu, respectively (Bube, 2003). In the case of camel meat products, the fat content of balangu $(20.57 \%)$ was significantly $(\mathrm{p}<0.01)$ than that of soye $(18.10 \%)$ and kilishi $(18.10 \%)$. The processing methods used in the current study involved further addition of vegetable oil which could be a major component of the higher fat contents recorded in the products. In meat, fat is the most variable and ranged from $2 \%$ in some free-living animals to 15 to $40 \%$ in domesticated animals intensively raised (Olomu, 1995). FAO (1997) reported beef with moderate fat $(18 \mathrm{~g} / 100 \mathrm{~g})$ to contain $63 \%$ moisture and $235 \mathrm{kcal}$ of energy.

The ash content of raw camel meat (2.0\%) was significantly higher than that of beef $(1.2 \%)$. Ash is a measure of inorganic contents of dry matter and determine the mineral concentrations. Kilishi products of both camel meat $(4.7 \%)$ and beef $(4.2 \%)$ had the highest ash contents $(p<0.05)$. The mineral composition of processed camel meat and beef are shown in Table 3. The sodium (Na) content of raw camel meat $(2.02 \mathrm{mg} / \mathrm{g})$ and raw beef $(1.23 \mathrm{mg} / \mathrm{g})$ were much lower than in all the products. This could be due to addition of table salt during processing. The potassium content of camel meat soye $(7.45 \mathrm{mg} / \mathrm{g})$ and beef soye $(4.66$ $\mathrm{mg} / \mathrm{g}$ ) was lower than that in other products. Potassium is a major intracellular cation and is involved in osmotic regulation of tissue fluids and in acid-base balance. Animals on free range that graze forage tend to have high potassium level in their tissue compared to browsers (McDowell et al., 1983). The calcium, magnesium, copper, and iron contents of the products increased due to processing. These results are in line with the report of Aduku and Olukosi (2000) that the percentage concentration of minerals in processed meat increased by the addition of salts and seasonings.

Camel meat products contains more minerals than beef products except for copper $(5.15 \mathrm{mg} / \mathrm{g})$ in beef soye which is higher than that of camel meat soye (4.65 $\mathrm{mg} / \mathrm{g})$ and iron $(1.43 \mathrm{mg} / \mathrm{g})$ of beef soye higher than that of camel meat soye (1.30 $\mathrm{mg} / \mathrm{g}$ ). These variations could be attributed to species differences associated with mineral contents in feed and flesh.

The sensory evaluation ratings of different meat products are shown in Table 4. The colour of beef and camel meat soye were rated 7.8 and 7.5 and kilishi rated 7.3 and 7.4, respectively. These ratings were significantly $(\mathrm{p}<0.05)$ higher than that of balangu of both beef and camel meat rated satisfactory (6.0). 
The colour of food strongly influences consumer decision to eat or not and form initial means of visual assessment to determine acceptability. An objectionable colour may preclude further evaluation of touch and smell to casual consumer (Srilakshmi. 2002). The texture and tenderness of both beef and camel meat soye, balangu and kilishi showed no significant difference and were rated between satisfactory (6.0) and very good (7.0). The meat texture and tenderness are not easily distinguished by un-trained consumers. Tenderness is one of the important features of meat product. The texture is another important characteristic that determine meat acceptability. Other sensory attributes became less important in tough meat (Miller et al., 1995)

The flavour of camel meat soye was rated (8.1) very good compared to balangu and kilishi of both camel meat and beef. The flavour of camel balangu was rated sufficient (4.0) significantly $(\mathrm{p}<0.05)$ lower than camel meat kilishi rated satisfactory (6.4). The flavour is the sum of the olfactory response to aromatic and volatile food substances easily discerned by consumers. It is a combined perception of taste, smell and mouth feel (Leora, 1994). Flavour is a result of chemical stimulation of receptors in both the oral and nasal cavities by variety of different classes of chemicals that are either present in food or are formed during processing (Neilgard et al., 1991). The flavour ingredient may be used to enhance food acceptability (James, 1993).

The overall acceptability rating of camel meat (8.5) and beef (8.0) soye of between very good and excellent were significantly $(\mathrm{p}<0.05)$ higher than camel meat kilishi rated satisfactory (6.4).

Camel meat balang $u$ was rated between 4-sufficient and 5-mediocre and was the lowest rating. Olomu (1995) opined that the acceptability of meat and its products is influenced by factors such species, age of the animal, handling after slaughter and cooking method.

Table 4: Sensory evaluation of definitely processed beef and camel meat.

\begin{tabular}{|c|c|c|c|c|c|c|c|c|}
\hline \multirow[t]{2}{*}{ Parameter } & \multicolumn{3}{|c|}{ Camel meat } & \multicolumn{3}{|c|}{ Beef } & \multirow[b]{2}{*}{ LS } & \multirow[b]{2}{*}{ LSD } \\
\hline & soye & balangu & kilishi & soye & balangu & kilishi & & \\
\hline Colour & $7.8^{\mathrm{a}}$ & $6.9^{\mathrm{ab}}$ & $7.3^{\mathrm{a}}$ & $7.5^{\mathrm{a}}$ & $6.0^{\mathrm{a}}$ & $7.4^{\mathrm{a}}$ & $*$ & 0.42 \\
\hline Texture & 6.8 & 6.7 & 6.8 & 6.8 & 6.5 & 7.1 & ns & - \\
\hline Tenderness & 6.7 & 7.1 & 7.4 & 7.1 & 5.5 & 6.5 & ns & - \\
\hline Flavour & $7.9^{\mathrm{ab}}$ & $7.5^{\mathrm{ab}}$ & $7.5^{\mathrm{ab}}$ & $8.1^{\mathrm{a}}$ & $4.0^{\mathrm{c}}$ & $6.4^{\mathrm{b}}$ & $*$ & 0.89 \\
\hline Acceptability & $8.0^{\mathrm{ab}}$ & $7.1^{\mathrm{ab}}$ & $7.1^{\mathrm{ab}}$ & $8.5^{\mathrm{a}}$ & $4.7^{\mathrm{c}}$ & 6.6 & $*$ & 0.91 \\
\hline
\end{tabular}

\section{Conclusion}

It was concluded that processing camel meat and beef into balangu, kilishi and soye increased protein, fat and ash concentrations. The concentration of both major and trace minerals are higher in camel meat than beef except $\mathrm{Cu}$ content. Processed camel meat products were similar to beef in texture and tenderness and compare favourably in flavour and overall acceptability. Soye of both camel meat and beef is the most preferred product. It was It was recommended that camel meat be adopted for use in soye, kilishi and balangu making at small scale and commercial production levels.

\section{Acknowledgment}

The authors wish to thank the management of the Bayero University for providing the funds used in part of the 
research through its grant no. (URC/05/022).

\section{References}

A.O.A.C. (1990). Association of Official Analytical Chemists. Official Methods of Analysis, 15 ${ }^{\text {th }}$ Edition, Washington D.C.

Aduku, O.A. and Olukosi, J.O. (2000). Animal Products, Processing and Handling in the Tropics. Living Books series G.U. Publications, Abuja 96pp.

Alonge, D.O. and Hiko, A.A. (1981) Traditional Methods of Meat Preservation in Nigeria.

Proceeding of West African Farmers Federation. March to April, pp 19-21

Anonymous (2010) Kano State. http://en.wikipedia.org/wiki/Kano_St ate

Anon, (2008). Camel. http://www.answers.com/topic/camel

A n o n, $\left(\begin{array}{llll}2 & 0 & 0 & 2\end{array}\right)$. C a m e 1 . www.arab.net/camels

Apata, E.S., Soniran, G.O., Taiwo B.B.A., Oke, B.D., Eniolorunda, O.O., Ogungebesan, M,A. and Badejo, V.O. (2008). Consumers' evaluation on eating qualities of some meat types cooked by different methods. In: Animal Agriculture Towards Millennium Development in Nigeria. O.A Adeyemi. A,M Ogungbesan, A,O Dada, O.O. Eniolorunda, H.A. Awojobi D.B. Oke and J.A Agunbiade (Eds). Proceedings of the $33^{\text {rd }}$ Annual Conference of the Nigerian Society for Animal Production held at Olabisi Onabanjo University, Ayetoro, Ogun State. 16th 20th March.

Barnerjee, G.C. (2005) A Textbook of Animal Husbandry. $8^{\text {th }}$ Edition, Oxford and IBH publishing Co. Ltd. New Delhi. Pp 1-250.
Bube, M.M. (2003) Nutritional Evaluation of Meat from Variuos Animal Species Processed by different Methods. Unpublished Ph.D Thesis, Abubukar Tafawa Balewa University, Bauchi. 82pp

Casey, N.H. (1992). Got meat in human nutrition, Proceedings of International Conference on Goats, held at Indian Council of Agricultural Research, New Delhi, March, 1992. pp 582-598.

Census (2006). National population Commission, Abuja, Nigeria.

Dawood A. A. (1995). Physical and sensory characteristics of NajdiCamel meat. Meat Science 39(1):5969.

DAA (2007). Nutritional composition of red meat. Dietitians Association of Australia. Gale Group.

Egbunike, G.N. and Okubanjo, A.O. (1999). Effects of processing upon the quality of Nigerian meat products. Livestock Production Science 59:155163.

FAO. (1997). Agriculture, Food and Nutrition for Africa. A Resource Book for Teachers in Agriculture. Food and Agriculture Organization, Publication Management Group.412 pp.

Farouk, M.M., Price, J.F., Salh. A.M. and Burnell, R.J. (1992). Effect of post exsanguinations infusion of beef on composition, tenderness and function properties. Journal of Animal Science .70(9):2773

Gracey, J.F. and Collins, D.S. (1992) Meat Hygiene 9th edition. Education Low Priced Book Scheme, London. $548 \mathrm{p}$.

Igene, J.O. and Abulu, E.O. (1984) Nutritional and Bacteriological Characteristics of Tsire-Type Suya, A Popular Nigerian Meat Product. Journal of Food Protection 47: 193- 
196

Igene, J.O. and Mohammed, I.D. (1983) Consumer Preferences and Atitude to Suya: An Indigenous Meat Product. Annals of Borno 1:169-178

Igene, J.O. and Farouk, M.M. (1990) Preliminary studies on the traditional processing of Kilishi. Journal of Science Food and Agriculture 50:8998

Ikeme, A.I. (1990) Meat Science and Technology. 1st Edition Africa FEP Publishers Ltd, Onitsha, 320ppp.

James, G. (1993). Packaging, storage and delivery of ingredients. Journal of Food Technology 47(8): 54-68.

Joseph. J.K, Momoh, R.D., Omotosho, O.A. and Ladde, A.A. (1995). Relationship between tested organoleptic qualities and the consumption pattern $\mathrm{c}$ selected meat types in three Nigerian cities. Agro Science. 1:65-68.

KNARDA (2001) Kano Agricultural and Rural Development Authority. Meteorological station reports. Temperature Record Book, Land Management Unit No. 11:1-3.

Kurtu, M.Y. (2004). An Assessment of the Productivity for Meat and the Carcass Yield, of Camels and the Consumption of Camel in Eastern Region of Ethiopia. Tropical Animal Health and Production. 31 (1):65-76.

Larson, E.M., Holm, E.T., Marchello, M.J. and Slander, W.D. (1992). Physical and sensory characteristics of fresh pork leg roast-cooked at low temperatures. Food science 57(6):1300-1303.

Lathan, M.C. (1997). Human Nutrition in the Developing World, FAO. Rome. Italy. 508pp

Lawrie, R.A. (1985). Meat Science. 4th Edition, Pergamon Press. 97pp

Leora, C.H. (1994). Overcoming flavour challenges in low fat frozen meat. Journal of Food Technology. 48(2): 98-105

Martin, A.M. (2001) The future of the world food system, Outlook on Agriculture 301(1):11-19

Maya, E. (2004) Lagosians and Camel. The Sun News Online. December 20, 2004.

McDowell, C.R., Conrad, J.K., Ellis, G.L. and Loosli, J.K. (1983). Minerals For Grazing Ruminants In Tropical Regions. University of Gainesville: Florida.Miller, F.M., Hower, I.C., Cook, K.D., Guerra, A.L. and Huffman, L. (1995) Consumer aceeptability of beef steak tenderness in home and restaurance. Journal of Food Science 60 (50):124-133

Muhammad, B.F. (2008) Camel meat utilization in Kano, Nigeria: Consumers' Perception. Journal of Science, Management and Technology: 1(2):1-8

Muhammad, B.F. and Akpan, I.N. (2008) Camel (Camelus dromedarius) meat utilization in Kano-Nigeria II: Post-slaughter handling and marketing wholesale meat cuts. Research Journal of Animal Science 2 (4): 113-117

Muh amm ad, B.F. and A.M. Muhammad (2007) Effects of packaging material and storage period on microbial load and organoleptic properties of Kilishi. Tropical Journal of Animal Science. 10(1\&2):217-220.

Neilgard, S., Civille, G. and Carr, T. (1991) Sensory Evaluation Technique. $2^{\text {nd }}$ Ed. CRS Press, Inc. Baca Raton, Florida.

Oguntona, E.B. and Akinyele I.O. (1995) Nutrient Composition of Commonly Eating Foods in NigeriaRaw, Processed and Prepared. Food 
Basket Foundation International. 131 pp

Okubanjo, A. (1988). Beef cooking practices in a segment of an urban Nigeria populace, Nigerian Journal of Animal production 15: 15-22.

Olomu. J. M. (1995). Monogastric Animal Nutrition, Principles and Practices. Living Books Series. $320 \mathrm{pp}$.

Omojola, A.B. (2008) Yield and Organoleptic Characteristics of Suya (an intermediate moisture meat) Prepared from three different Muscles of a Matured Bull. African Journal of Biotechnology 7:2254-2257

Srilakshmi, B. (2002). Food Science, $2^{\text {nd }}$ edition, New Age International Ltd. $372 \mathrm{pp}$

Steel, R. G. P. and Torrie, J. H. (1980). Principles and Procedure of Statistics. A Biometrical Approach. McGraw-Hill Books Company Inc., New York. $276 \mathrm{pp}$

Wilson, R.T. (1984). The Camel. Longman Group Limited, London. $223 p p$

Williams A.A. (1982). Scoring method used in sensory evaluation analysis of foods and beverages at Long Ashton Station. Journal of Food Technology.17:163-173 